\title{
Investigating Factors Influencing Community Acceptance of Established Hydroelectric Dams in Northern Sweden
}

\author{
Sara Löwgren ${ }^{1}$ \\ School of Global Studies, University of Gothenburg, Sweden
}

\section{Abstract}

Hydroelectric dams are controversial for their negative impacts on nearby communities. To study communities' perceptions of these impacts, one tool available is the social acceptance framework. However, previous studies have mostly looked at recently built dams, and the literature lacks a longitudinal perspective. In Northern Sweden, the town of Jokkmokk on the Lule River offers a great opportunity to study which factors influence community acceptance of hydroelectric dams, decades after construction is over. This study employed a holistic research approach, combining historical contexts with empirical data from an online survey and interviews with Jokkmokk residents. Community members are most concerned about the hydroelectric dams' economic and ecological impacts, and about feeling exploited. Distributional justice seems crucial to community acceptance, but trust also plays a role. To improve community acceptance of hydroelectric dams in Jokkmokk, Swedish policymakers need to consider mechanisms for sharing revenues and measures for mitigating the ecological impacts.

Keywords: community acceptance, dams, distributional justice, hydropower, social acceptance, Sweden

Recommended citation (APA 7th ed.)

Löwgren, S. (2021). Investigating factors influencing community acceptance of established hydroelectric dams in Northern Sweden. Human Ecology Review, 27(1), 101-124. doi.org/ 10.22459/HER.27.01.2021.06

1 Corresponding author: guslowgsa@student.gu.se. 


\section{Introduction}

\subsection{Hydropower globally}

In the face of severe anthropogenic climate change, where energy production contributes greatly to greenhouse gas emissions, finding affordable low-carbon alternatives is crucial to mitigating climate change while meeting human energy needs (IPCC, 2018). Although not without carbon emissions (Deemer et al., 2016), hydropower is currently the largest source of renewable energy, accounting for $70 \%$ of global renewable energy production (World Energy Council, 2018). Hydropower's share is predicted to continue to increase as large, fast-growing countries like Brazil and China construct new dams (International Energy Agency, 2018). Hydroelectric dams are controversial; although dams generate large amounts of electricity, they also disrupt the hydrology and ecology of rivers, interfering with the natural migration and food supply of aquatic species (Mueller et al., 2011). Furthermore, while large hydropower projects can bring nearby communities benefits, such as investment in infrastructure, access to electricity, and creation of jobs, they have also altered rivers and displaced millions of people globally, often resulting in severe socioeconomic and cultural losses that disproportionately harm indigenous and traditional communities (World Commission on Dams, 2000).

The complex nature of hydroelectric dams makes them a site where conflicting interests collide, and many institutions and researchers are beginning to recognize the need for new governance to "reconcile economic, social, and ecological concerns related to hydropower" (Lindström \& Ruud, 2017, p. 11). Pursuant to broadly accepted principles of the role of justice in environmental management and decision-making, the new governance principles should strive to ensure that the communities impacted by recently built or established hydroelectric dams feel that the dams are acceptable.

\subsection{Hydropower in Sweden}

One of the most interesting places to study community acceptance of hydropower is Sweden, a social-democratic, Northern European country that takes pride in its ambitious climate policies and relies on hydropower for approximately $40 \%$ of its electricity generation (Statistiska Centralbyrån, 2017). Most of Sweden's hydroelectric dams were built during the construction era (or the "era of exploitation," as Lindström and Ruud (2017) called it), that lasted from the mid-1940s through the mid-1970s.

2 Intergovernmental Panel on Climate Change. 
In Sweden, there is a geographical divide between where the hydropower is produced and where it is used. Most of Sweden's 10 million people live in the southern third of the country, while most of the hydroelectric dams are located in the north, where there are large rivers that flow east from the mountains into the Gulf of Bothnia and the Baltic Sea. The communities in dammed watersheds in Northern Sweden are important sites to study the factors influencing community acceptance of hydroelectric dams, several decades after the dams have been built. This is what I did, using the case study of Jokkmokk in Northern Sweden. In the remaining introductory sections, I review the history of Swedish hydropower (1.2.1), before introducing the study site (1.3). Then I describe a few Swedish policies that impact communities with hydroelectric dams (1.4), before introducing this study's theoretical framework (1.5) and my research question (1.6).

\subsubsection{The history of Vattenfall and Swedish hydropower}

In 1909, the Swedish government founded Vattenfall, the arm of the government tasked with developing hydropower in the country. But demand for Swedish hydropower was jumpstarted following World War II, as Sweden's intact industries found a new market in the rebuilding of Europe. Thus began Sweden's construction era for hydroelectric dams. During this time, most of the large rivers in Northern Sweden were dammed.

By constructing dams, Vattenfall supplied not only jobs but also-as an arm of the social-democratic government-provided housing, medical clinics, schools, public spaces, and sports facilities to the workers whom they brought from the populous south into the sparsely populated, traditionally indigenous north. In a short period of time, Northern Sweden became an attractive part of the country to earn a comfortable living.

The end of the construction era came in the 1970s, partially because most of the large rivers of the north had been dammed by then and partially because Vattenfall began to experience strong resistance from river conservationists. The battles over Swedish rivers resulted in an initial agreement - the Peace in Sarek—in 1961 and legislation protecting Sweden's last free-flowing rivers in 1970 (Lindström \& Ruud, 2017). At the end of the construction era, many northern communities saw a rapid decline in jobs, population, and financial support (Strand, 1984).

\subsection{Introduction to the study site: The Lule River and Jokkmokk}

\subsubsection{Hydroelectric dams on the Lule River}

During the construction era, one of the rivers that was dammed is Luleälven, or the Lule River, which, with a mean discharge of $506 \mathrm{~m}^{3} / \mathrm{s}$ is one of the largest rivers in Sweden (Länsstyrelserna \& Vattenmyndigheterna, n.d.). With 15 hydroelectric 
dams, the Lule River alone accounts for an annual production of 10 terawatt-hours (Vattenfall, 2019), or 10\% of Sweden's total electricity generation. A large part of the Lule River watershed and most of the hydroelectric dams are located in the municipality of Jokkmokk, as shown in Figure 1.

\subsubsection{The history, demographics, and economy of Jokkmokk}

Before dam construction began on the Lule River, the Jokkmokk area had been inhabited by different groups of Sami people for thousands of years. In the mid1800 s, the municipality had a population of 1,500 - Sami and nonindigenouspeople. As shown in Figure 1, Jokkmokk, comprising 18,000 square kilometers, encompasses most of the Lule River watershed, and so the construction era changed Jokkmokk.

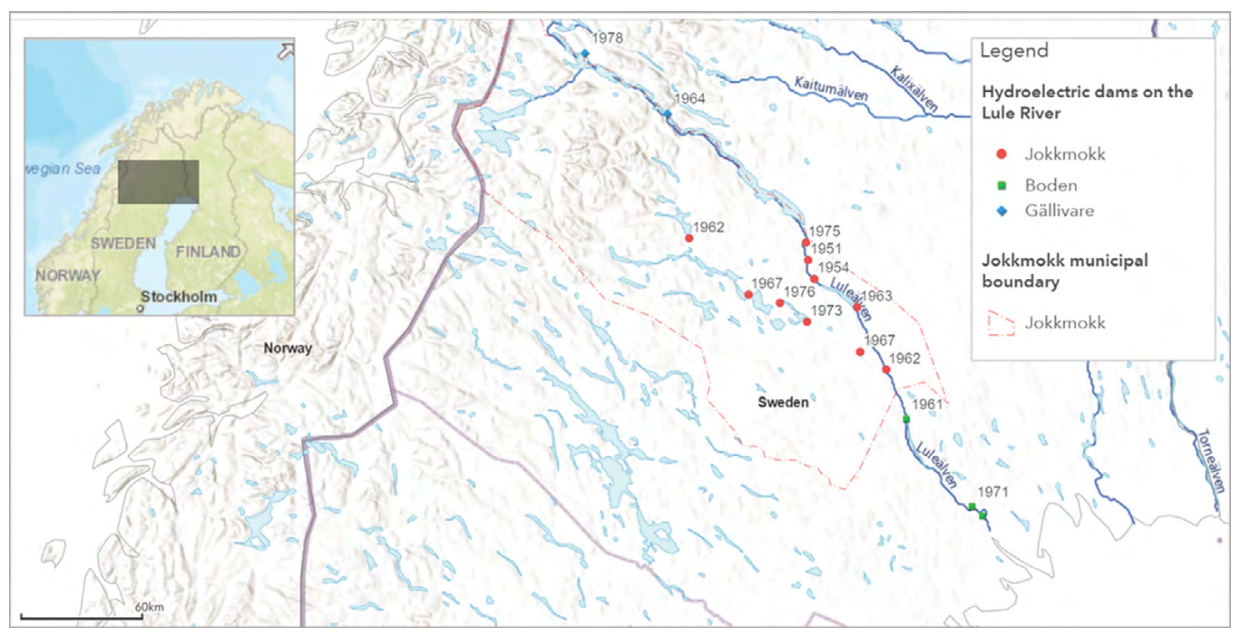

Figure 1. Map showing the location, municipality, and construction year of the hydroelectric dams on the Lule River in Northern Sweden

Source: Created by the author, using data from Vattenfall (2019) and Esri (2013).

As shown in Figure 1, from the mid-1940s through the mid-1970s, Vattenfall constructed 15 dams on the Lule River. This resulted in Jokkmokk's population growing exponentially. By 1960, the population of Jokkmokk peaked at around 12,000 people. This was a 10 -fold increase: during the same period, the population of the whole country, for comparison, roughly doubled. At that time, Vattenfall employed around 1,500 people in Jokkmokk (Strand, 1984). Jokkmokk's population has declined since the 1960s (in 2019, the population was 4,900). Some key demographic and economic information about Jokkmokk today is shown in Table 1. 
Table 1: Comparison between Jokkmokk and the national average on several demographic indicators

\begin{tabular}{|l|c|c|}
\hline Category & Jokkmokk & Sweden national average \\
\hline $\begin{array}{l}\text { Population density (people per square } \\
\text { kilometer) }\end{array}$ & 0.2 & 24.8 \\
\hline \% of people older than 65 & 27 & 22 \\
\hline \% of people with a college degree & 21 & 41 \\
\hline Largest political party & Social democrats (left) & Social democrats (left) \\
\hline Unemployment rate (\%) & 6 & 6 \\
\hline Large employers other than public sector* & $\begin{array}{c}\text { Construction, energy } \\
\text { production }\end{array}$ & $\begin{array}{c}\text { Service industry, } \\
\text { IT development }\end{array}$ \\
\hline $\begin{array}{l}\text { \% working in energy and environment } \\
\text { sector }\end{array}$ & 7 & 1 \\
\hline
\end{tabular}

Note. ${ }^{*}$ Includes public health care and education.

Source: Data collected from Statistiska Centralbyrån [Statistics Sweden] (n.d.).

Jokkmokk is a typical rural town, with a sparse, aging population that has lower levels of education than the national average. The unemployment rates are the same in Jokkmokk and Sweden at large, but the largest employment sectors (other than public sector) differ. Many urban Swedes work in the service industry or IT development, but in Jokkmokk, many people work in sectors that rely on natural resource use, such as construction and energy production. The energy sector, which in Jokkmokk is dominated by Vattenfall, employs a large part of Jokkmokk's population. Vattenfall has 100-120 employees in Jokkmokk.

The history of Jokkmokk over the last century is deeply interconnected with the history of Swedish hydropower, and changes in Swedish politics and policies are reflected in Jokkmokk. It is therefore relevant to review some key policies that shape Swedish economics and ecological restoration.

\subsection{Policies that impact hydropower communities}

\subsubsection{National economic policies}

Since the end of the construction era, Vattenfall has changed its structure and focus. For example, in 1992, Vattenfall became incorporated as a profit-driven, multinational company owned by the Swedish government and in 1996, Sweden opened its electricity market to international trade. During this time, Vattenfall withdrew much of its former financial support from Jokkmokk. But there are also broader economic policies that shape rural communities with hydroelectric dams. The following section describes four such policy issues: the public community service fund, Swedish centralization policies, corporate property taxes, and revenue sharing. 
Communities that have been impacted by hydropower developments can seek financial support for public community service projects from a fund (Swedish bygdemedel). The fund is managed by the County Administrative Board (Swedish Länsstyrelsen) and supports small projects such as repairing community centers and building trails. Jokkmokk typically receives SEK20 million (USD2.31 million) per year from the community service fund.

Under the Swedish centralization system, government grants are a major source of income for all rural municipalities. Only Stockholm and two of its neighboring municipalities pay more to the grant system than they receive (Ekonomifakta, 2020). Jokkmokk is one of the municipalities that receives the most government grants per capita: SEK20,600 (USD2,400) per year compared to the county average of SEK5,700 (USD660) per year.

Since 1985, Swedish property taxes are collected at a national rather than municipal level. The property tax levels for hydropower stations, based on assessed value, have fluctuated from $0.5 \%$ up to $2.0 \%$, but in 2020 it once again became $0.5 \%$ to ensure that hydropower as a source of renewable energy remains economically feasible (Finansdepartementet, 2016).

Sweden is one of few European countries where the municipality and county in the location of a natural resource industry do not directly receive the revenue from the industry's property taxes. Some estimates show that if Sweden shared revenues using the same systems as Norway, the municipality of Jokkmokk would receive nearly SEK300 million (USD35 million), or SEK60,000 (USD6,900) per capita, per year (Hannu, 2014).

\subsubsection{The European Union Water Framework Directive}

Since the European Union adopted its Water Framework Directive (WFD) in 2000 to protect the region's water bodies, hydroelectric dams have been a source of disagreement. On the one hand, member states must prevent deterioration of their water bodies. On the other hand, hydroelectric dams generate vast amounts of renewable energy, and the WFD places less stringent requirements on dammed rivers. However, some member states apply these exemptions too generously and thus fail to adequately protect and restore their dammed rivers (Söderasp, 2018).

This is the case in Sweden, which has repeatedly been criticized for its weak implementation of the WFD. Swedish environmental law regulates the minimum flow in dammed rivers, but many of the old dams on the Lule River lack environmental adaptations adequate to protect and restore aquatic species (Renöfält et al., 2010). The dams on the Lule River have created the longest dry channel in Europe, altered the river's flow regime, reduced natural flooding, and changed the concentration and transportation of different natural elements (Siergieiev et al., 
2014)_changes which have fragmented not only the river but also the surrounding riparian area (Jansson et al., 2017). The Lule River meets neither its ecological nor chemical standards required under the WFD (Vattenmyndigheterna et al., 2020).

To comply with the WFD, Sweden may, for example, need to require dam operators to install fish ladders or to spill extra water into the river channel, but these measures are costly and may reduce electricity production. In a 2014 report, Vattenfall suggested that complying with the WFD would reduce the production of Swedish hydropower by $20 \%$, and the company argues that rather than impacts on specific rivers, assessments should consider the global environmental benefits of fossil-free energy production (Bostorp et al., 2014). Ecological impacts are one of several concerns making hydropower an important subject of community acceptance.

\subsection{The social acceptance framework}

Reconciling multilevel concerns to remedy the negative impacts of hydropower requires a theoretical framework that allows researchers to understand the concerns of project-affected communities. One such framework is the well-cited social acceptance framework. Social acceptance is a complex, dynamic, and polycentric process (Wolsink, 2018) and a framework that Wüstenhagen et al. (2007) originally defined in terms of three main dimensions: market, sociopolitical, and community acceptance. For this study, community acceptance is the most relevant dimension.

Community acceptance here refers to acceptance by the residents around the site of an energy development project (Wüstenhagen et al., 2007), and it consists of three factors: distributional justice (how burdens and benefits are shared), procedural or participatory justice (how decision-making and management are done), and trust (in the company or the owner). The justice factors, importantly, refer to people's perception of justice (Wolsink, 2018).

\subsubsection{Distributional justice}

Distributional justice reflects whether the burdens and benefits of a project are equitably shared. Distributional justice extends beyond self-interest; it is not a matter of people maximizing their benefit as much as it is a matter of people perceiving the outcome of a project as fair (Gross, 2008). Empirical studies have identified that, among other things, distributional justice depends on people's perception of local benefits (Chandy et al., 2012; Evans et al., 2011; Hou et al., 2019; Pidgeon \& Demski, 2012; Tefera \& Stroosnijder, 2007) and perception of risk and risk-sharing (Hagen \& Pijawka, 2015; Liu et al., 2013) associated with the project in question. Distributional justice can also be affected by displacement, for example in Ethiopia (Tefera \& Stroosnijder, 2007). 
Relating to distributional justice associated with dam projects, researchers have found that communities in Greece (Malesios \& Arabatzis, 2010), Switzerland (Kellner, 2019), India (Chandy et al., 2012), Ethiopia (Tefera \& Stroosnijder, 2007), and Sweden (Kataria, 2009) were concerned about ecological destruction, which may harm communities who depend on the rivers and who are not the main beneficiaries of the dam projects. Although some studies consider ecological impacts as separate from distributional justice (Tabi and Wüstenhagen, 2017), in this study, I consider ecological impacts to be a part of distributional justice.

\subsubsection{Procedural justice}

As emphasized particularly by Lind and Tyler (1988), procedural justice refers to people's perception of fairness of processes. Theories of procedural justice suggest that people are more likely to accept the outcome of a decision if they feel that the decision-making process was fair. Some scholars even argue that perceiving the process as fair is, in some cases, more important to accepting the project than perceiving the outcome as fair. The decision-making processes may include access to information, the ability to vote or participate, or interactions with and perception of officials (Gross, 2007), both in planning the dam and operating it. Empirical studies have found that drivers of procedural justice include participatory planning and polycentric governance (Kellner, 2019; Tabi \& Wüstenhagen, 2017) and obstacles include past political tension and cultural barriers (Gross, 2007; King, 2010). When procedural justice and distributional justice are involved in community resistance, NIMBYism $^{3}$ is often an oversimplification (Wüstenhagen et al., 2007); rather than selfishness, communities resist local projects when they feel the processes are inequitable and lack fairness (Evans et al., 2011).

\subsubsection{Trust}

Trust is a complex factor that can represent one's willingness to rely on and be vulnerable with another actor; take the form of expecting someone else to act in line with one's own needs and wants; and replace complete knowledge in giving one the courage to act (Huijts et al., 2007). Trust in regulatory authorities can shape community acceptance of hydropower (Bronfman et al., 2015). Trust can be viewed not only as the third factor of community acceptance but also as a crucial element underlying both procedural (Tabi \& Wüstenhagen, 2017) and distributional justice (Hou et al., 2019).

\subsubsection{The complex nature of community acceptance}

The different roles of trust exemplify how distributional justice, procedural justice, and trust are all important factors of community acceptance, interacting and reinforcing each other in complex ways. The factors can blend, for example when

3 An abbreviation of 'not in my backyard,' NIMBYism is a person or community's opposition to locating new development(s) in their neighborhood or proximity. 
project-impacted people feel that the outcome is unfair (distributional injustice) in part because they felt that the decision-making process was unfair (procedural injustice) (Evans et al., 2011; Gross, 2008; Pidgeon \& Demski, 2012) or because they distrust the intentions of the project owner or operator (Bronfman et al., 2015; Evans et al., 2011; Hou et al., 2019; Huijts et al., 2007).

\subsection{Research question}

Many scholars (Evans et al., 2011; González et al., 2016; Wolsink, 2018) agree that community acceptance is complex and requires a multifaceted research approach, but most studies of community acceptance and local perception of energy projects, particularly dams, only assess planned or recently constructed projects, and the topic of community acceptance in communities that have been living with hydroelectric dams for decades remains understudied.

By studying the factors influencing community acceptance of hydroelectric dams in Jokkmokk, a town on the Lule River that has had hydroelectric dams for several decades, I address the following question: What factors most influence community acceptance of hydroelectric dams decades after the dams were built, and what are the implications for long-term hydropower policy? In researching this question, my study contributes a longitudinal perspective on community acceptance of hydroelectric dams, which, keeping in mind that social acceptance is a dynamic process (Gross \& Dumaresq, 2014; Huijts et al., 2007; Wolsink, 2018), is relevant for formulating long-term sustainable energy solutions. This study responds to Lindström and Ruud's call for further research on reconciling concerns, explores the notion of benefit-sharing, and attempts to begin to bridge the temporal gap in the social acceptance literature.

\section{Methodology}

Hydropower is a human-ecological topic that engages multiple disciplines, and adequately studying the social acceptance of hydroelectric dams requires a transdisciplinary approach. To do this, I used multiple methods, inspired by Gross's (2008) investigative, holistic, and transdisciplinary research approach. Gross based her research approach on Layder's adaptive theory, which she characterized as "continuous cycling between the theoretical aspects of the research and the empirical findings" (Gross, 2008, p. 131), emphasizing the importance of coupling historical, legislative, and theoretical contexts with empirical data. Gross used findings from her previous empirical research in the study community to inform her interview questions. My research method takes a similarly transdisciplinary, iterative approach, collecting data in two phases where the first, a survey, informed the second, semi-structured interviews, grounding my empirical findings in a historical context. The following 
section outlines my methodology for collecting and analyzing empirical data through an exploratory survey (2.1) and explanatory semi-structured interviews (2.2) and presents demographic information about the study participants (2.3).

\subsection{Phase 1: Survey}

In the first phase of data collection, I created an exploratory online survey aimed at identifying what impacts of the Lule River hydroelectric dams Jokkmokk residents felt most strongly about. Informed by the literature on social acceptance of dams, the survey contained questions about economic impacts (job opportunities, economic dependence, inflow of workers, effects on tourism, costs for the town), ecological impacts (erosion, water quality, fish migration, migration of other aquatic species), perception of risk of dam failure, impacts of dams on river recreation (fishing, water sports, activities on the ice), and access to information (about job vacancies at the hydroelectric company and response to dam failure). The survey consisted of 5-point Likert scales and several open-ended questions. The first page informed the respondent about confidentiality and stated that by moving to the next page, the respondent would consent to participate. The survey also collected demographic data.

I distributed the survey using Facebook, posting it in a large public group specific to the town of Jokkmokk with about 5,000 members. The survey was open for five weeks, mid-April through mid-May 2019, and I shared it in the group three times. 120 people completed the survey and the demographic data confirms that the group can be considered representative of Jokkmokk (age, main occupation, number of years living in Jokkmokk, and belonging to a minority group). At the end of the survey, respondents could volunteer to be interviewed by giving their name and contact information, but the page of identifying information was kept separate throughout the analysis of the survey responses.

I analyzed the survey data using an analysis of variance (ANOVA) test in RStudio, testing whether age, number of years living in Jokkmokk, and self-identification as belonging to the Sami people correlated to the Likert scale responses. By quantitatively analyzing the survey data, I could identify trends to be investigated in the second phase of data collection. I analyzed the open-ended questions by coding the written responses and identifying salient themes and interesting points. The survey thus identified areas that needed explanation and directly informed my interview questions.

\subsection{Phase 2: Interviews}

To understand the themes identified in the survey, I conducted 17 semistructured explanatory interviews in Jokkmokk during July 2019. Based on the survey respondents who had volunteered to be interviewed, I selected a group of interviewees that represented people of different ages and genders, ensuring that 
I had some interviewees who worked for Vattenfall as well as some interviewees who identified as Sami people. I interviewed as many of the 23 volunteers as possible, under existing time constraints. Some demographic information of the interviewees is shown in Table 2.

Drawing on findings from the survey, my interview guide contained open-ended questions aimed at exploring the interviewees' perceptions of the hydroelectric dams' economic and ecological impacts and the interviewees' perceptions of how benefits and burdens are shared. Examples of questions included: "Do you think the hydroelectric dams are important for Jokkmokk today? Has that changed over time?"; "Do you think there are benefits from the hydroelectric dams and if so, who benefits?"; and (in three separate questions) "What do you think about the relationship between Jokkmokk and [Q1] Vattenfall, [Q2] the Swedish government, [Q3] the South?”

Three interviews were conducted over the telephone, the others in person. The interviews lasted 30-75 minutes. All interviews were conducted in Swedish and the audio recorded. I transcribed all interviews within 24 hours after the interview. I used inductive coding — drawing on existing literature — and deductive coding (see Bernard et al., 2017), identifying themes such as benefit-sharing, feelings of exploitation, and need for mitigation of ecological impacts, that indicate which factors influence Jokkmokk residents' acceptance of the hydroelectric dams on the Lule River.

\subsection{Demographic information}

The study included 120 survey respondents and 17 interviewees. The demographic data on the participants is shown in Table 2.

Table 2: Summary of demographic information about survey and interview participants

\begin{tabular}{|l|l|c|c|}
\hline Category & Subcategory & Survey respondents \% & Number of interviewees \\
\hline \multirow{5}{*}{ Age (years) } & 18-25 years & 7.5 & 1 \\
\cline { 2 - 4 } & 26-45 years & 32.5 & 6 \\
\cline { 2 - 4 } & 46-65 years & 45.8 & 2 \\
\cline { 2 - 4 } & 66-75 years & 10.0 & 6 \\
\cline { 2 - 4 } & 76+ years & 4.2 & 2 \\
\hline \multirow{5}{*}{ Birth country } & Sweden & 97.5 & 17 \\
\cline { 2 - 4 } Jears lived in & Other than Sweden & 2.5 & 0 \\
\hline \multirow{5}{*}{ Jokkmokk } & 21+ years & 80.8 & 15 \\
\cline { 2 - 4 } & 11-20 years & 5.8 & 0 \\
\cline { 2 - 4 } & 5-10 years & 6.7 & 0 \\
\cline { 2 - 4 } & 1-4 years & 5.0 & 2 \\
\cline { 2 - 4 } & Less than 1 year & 0.8 & 0 \\
\cline { 2 - 4 } & Never lived there & 0.8 & 0 \\
\hline
\end{tabular}




\begin{tabular}{|l|l|c|c|}
\hline Category & Subcategory & Survey respondents \% & Number of interviewees \\
\hline \multirow{2}{*}{$\begin{array}{l}\text { Works/worked for } \\
\text { Vattenfall }\end{array}$} & Yes & n/a & 5 \\
\cline { 2 - 4 } & No & n/a & 12 \\
\hline \multirow{2}{*}{$\begin{array}{l}\text { Identifies as a Sami } \\
\text { person }\end{array}$} & Yes & 23.4 & 2 \\
\cline { 2 - 4 } & No & 76.6 & 15 \\
\hline
\end{tabular}

Source: Author's summary.

\section{Results}

In this section, I describe the results of the survey and the interviews. Section 3.1 presents the survey respondents' most important concerns: economic impacts (3.1.1), feeling exploited (3.1.2), and ecological impacts (3.1.3). Section 3.2 describes the interviewees' elaborations on these aspects and presents a complex picture of economic change over time (3.2.1), distribution of benefits (3.2.2), and the need for ecological mitigation (3.2.3).

\subsection{Survey responses}

\subsubsection{Economic impacts}

The survey showed that Jokkmokk residents perceive the economic impacts of the hydroelectric dams in varied ways. Rating their agreement with the statement "hydropower creates jobs for people from Jokkmokk," $48.0 \%$ of the respondents fully or mostly agreed, while $32.5 \%$ of respondents fully or mostly disagreed. Whether "Vattenfall has a positive impact on the Jokkmokk economy," $35.0 \%$ of respondents fully or mostly agreed, $44.2 \%$ fully or mostly disagreed, and $20.8 \%$ neither agreed nor disagreed. Two-thirds of respondents fully or mostly disagreed with the statement that "Vattenfall makes Jokkmokk economically stable."

The survey showed that people in Jokkmokk have divided views on the hydroelectric dams' impact on Jokkmokk's economy. The difference seemed related to the respondents' age: older respondents generally did not feel like Vattenfall creates local jobs, while younger people were more likely to agree with statements that the hydroelectric dams and Vattenfall benefit Jokkmokk's economy. The correlation between age and viewing hydroelectric dams and Vattenfall as good for the economy was statistically significant (ANOVA test, $p<0.0001$ ).

\subsubsection{Feeling exploited}

Throughout the survey's comment sections, many respondents described feeling exploited by Vattenfall and by urban Southern Sweden. One respondent wrote that "we deliver the electricity, but the revenue goes to Stockholm [the capital]." Another stated that the current tax policies are unfair and that "the Swedish government 
should reinvest some of the revenue in the infrastructure of the Swedish North." One respondent wrote that "Vattenfall ... suck everything they can out of here and bring the revenue South," while another pointed out that "they make fish ladders in the South, but not here."

\subsubsection{Ecological impacts}

More than half $(57.5 \%)$ of respondents were very or somewhat worried about the hydroelectric dams' ecological impacts on the Lule River. Respondents were most worried about the impacts on fish migration, and some of the comments mentioned that large salmon existed in the Lule River before it was dammed. One respondent described the hydroelectric dams as an "environmental massacre, [leaving the river as] an ecological desert."

A few respondents wanted to see the dams removed and highlighted that there should be alternative sources of income in Jokkmokk rather than hydroelectric dams. For example, one respondent noted that "ecology and growth must be somehow compatible, perhaps through nature-based tourism ... no jobs, no Jokkmokk," while another suggested that "a free-flowing river with large salmon could have been a great destination for nature tourism." However, most respondents who commented on ecological impacts did not speculate about dam removal; rather, they criticized the existing dams for being ecologically destructive. One respondent wrote "how are these dams allowed? Shouldn't Vattenfall follow the [EU] Water [Framework] Directive?"

\subsection{Interview results}

This section presents the results from the interviews, which, drawing on the survey responses, elaborated on the following three key themes: the economic impact of hydroelectric dams and Vattenfall over time (3.21), distribution of benefits (3.22), and ecological impacts (3.23).

\subsubsection{Jokkmokk's job market and economy over time}

The interviews explored why the age of study participants might influence their perception of the hydroelectric dams. Some older interviewees fondly remembered working for Vattenfall during the construction era. One man described how:

while construction was going on, our economy was booming. Everything was flourishing, local firms could deliver to Vattenfall, the economy was growing, and everyone's lives were getting better ... it felt like life would always be this way, and that would have been great. But when the dams were built, when everything was done, the decline came. (male, $76+$ years of age) 
Like this interviewee, many older interviewees who had experienced the construction era felt that it created false expectations for future employment and financial support, even though nobody expected Vattenfall to employ as many people today as during the construction phase.

Younger people, especially those currently working for Vattenfall, were less likely to compare the jobs from the construction phase to the present jobs, and they tended to express the view that current Vattenfall jobs are very important for their future in Jokkmokk. One male Vattenfall employee who had grown up in Jokkmokk but left after high school stated that "because I knew I could get a job with Vattenfall, we decided to move back up here" (male, 26-45 years of age).

Many of the older interviewees also remembered how the government used to financially support Jokkmokk through Vattenfall's infrastructure projects, and one woman speculated:

the financial situation in Jokkmokk is very difficult, perhaps because Vattenfall used to help with everything, they even paid for playgrounds and soccer fields. Our infrastructure and perhaps our economy are very much from that time. (female, $76+$ years of age)

A younger Vattenfall employee suggested that "the older generation are used to having everything given to them. They keep expecting Vattenfall to take care of everything, but that's just not the case anymore, not at all" (male, 26-45 years of age).

\subsubsection{Many benefits of hydroelectric dams leave Jokkmokk}

Interviewees of all ages felt that the monetary compensation Jokkmokk receives is inadequate and unfair, compared to how much revenue the hydroelectric dams on the Lule River produce. One interviewee stated that "the state collects the profit from everything we produce here" (female, $75+$ years of age) and another observed that "we are hardly getting anything back" (male, 26-45 years of age). While some thought that profits made by a state-owned company in the long run benefit everyone, most interviewees felt that the sharing of revenues was unfair. One man described the relationship between Jokkmokk and Southern Sweden like this:

It is like we are just good to have because we produce money ... I have been reluctant to use big words like "colony," but that is what it feels like. (male, 66-75 years of age)

Another stated that "it seems like everything, money and jobs, are flowing down the Lule River and continue down, south" (male, 26-45 years of age).

Also related to revenue-sharing, many interviewees brought up corporate property taxes. One interviewee, who had managed Jokkmokk's economy in the 1980s, described the time when the corporate tax policies changed, saying: 
in 1979, Vattenfall reported profits for the first time ... we [who worked for the town of Jokkmokk] were counting and already wondering what to do with all this money ... but then it all disappeared to the state. (male, 66-75 years of age)

"I get that we need dams and mines-I'm not opposed to the industry or anythingbut shouldn't there be some kind of fair-play?" (male, 26-45 years of age). Over half of the interviewees brought up the Norwegian system for sharing revenues between the Norwegian state and natural resource-rich small towns, suggesting that it would be possible for the Swedish government, too, to create a system that allows communities with natural resources to keep some of the revenue generated by the industry, rather than relying on government grants. While talking about the Norwegian system, one interviewee reflected on the impact of the Swedish system, saying that for the Jokkmokk residents, "having to always be on the receiving end is devastating. We are constantly asking for help, but only because they [the Swedish government] pulled the rug out from under us" (female, 66-75 years of age).

\subsubsection{Money is not everything - the need to mitigate ecological impacts}

Many interviewees reflected on the impacts of hydroelectric dams on the Lule River. One interviewee thought that "fishing was everything and walking down to the river used to be beautiful. Now it's not" (female, 66-75 years of age) and another felt that "so much was sacrificed for these dams ... the change in nature is irreversible" (male, 26-45 years of age).

A few interviewees brought up their ideas for how the ecological impacts of the hydroelectric dams on the Lule River may be mitigated or compensated. While some suggested that revenue-sharing could ameliorate the impacts of ecological destruction, too, others suggested that ecological damage should be compensated through ecological restoration. One interviewee, for example, said:

if Vattenfall would let just a little bit of water into the dry channel, even just a little bit ... it could become a little trickle full of life and make the dry channel beautiful again. (male, $70+$ years of age)

\section{Discussion}

The data showed that the people in Jokkmokk are particularly concerned about Jokkmokk's changing economy, the sense of unjust sharing of revenues, and the need to mitigate ecological destruction. This section places these results within the community-acceptance framework and literature (4.1), discussing the factors of distributional justice (4.1.1) and trust (4.1.2), outlines the limitations of the study and room for future research (4.2), and finally offers three recommendations to Swedish policymakers (4.3). 


\subsection{Related to the literature: Comparisons and contributions}

The three central pillars of community acceptance are distributional justice, procedural justice, and trust. This study suggests that decades after hydroelectric dams have been constructed, community acceptance is largely dependent on distributional justice and trust.

\subsubsection{Distributional justice}

Distributional justice plays an important role in the Jokkmokk community's acceptance of the hydroelectric dams; participants who accepted the dams often pointed to the benefits, for example, job opportunities, that the operation of the hydroelectric dams generate within Jokkmokk today. Most participants expressed that Southern Sweden, Stockholm, and/or Vattenfall collect the benefits of hydropower, such as revenue from electricity sales and taxes, without offering adequate compensation to Jokkmokk and Northern Sweden-an example of distributional injustice hindering community acceptance. My data supports the common understanding that perception of local costs and benefits influences local acceptance of renewable energy projects (Chandy et al., 2012; Evans et al., 2011; Hou et al., 2019; Pidgeon \& Demski, 2012; Soland et al., 2013; Tefera \& Stroosnijder, 2007).

My results differ from two studies of social acceptance of dams in Switzerland, in which Tabi and Wüstenhagen (2017) and Kellner (2019) suggested that distributional justice seemed less important than factors such as procedural justice, ecological impacts, ownership, or current political events. One of the most apparent reasons that the Swiss studies differ is that my study focused on a community where the renewable energy project has been in place for a long time and many participants were not yet born when the most important decisions were made. This would decrease their perception of the significance of procedural justice around the creation of the dams. In the case of Tabi and Wüstenhagen, it is important to note that they surveyed people across Switzerland, not exclusively members of a community physically located near hydroelectric dams. Another important factor is that Switzerland already has a system in place for sharing tax revenue on water resources.

Distributional justice is not only related to monetary values; my study showed that whereas some participants feel that money could adequately compensate for the loss of the river, others feel that rather than compensated, ecological impacts should be mitigated. For example, participants suggested that some water could be released to somewhat restore the dry sections of the river channel. 
The ecological impacts of dams matter for acceptance, not only in the nearby communities but also for consumers of hydroelectricity, as shown in a survey of consumer choice in Sweden (Kataria, 2009) and Switzerland (Tabi \& Wüstenhagen, 2017). Kataria's choice experiment showed that Swedish consumers are willing to pay more for hydroelectricity, if the hydroelectric dams are fish friendly, release adequate amounts of water, and ensure good conditions for birdlife. As Tabi and Wüstenhagen (2017) stated in response to Kataria's results, governments should "strike a careful balance between energy and environmental policy objectives" (p. 771).

\subsubsection{Trust}

To some interviewees, particularly younger people currently employed by Vattenfall, the company and the hydroelectric dams symbolize a reliable source of income and job security. Seeing Vattenfall as a stable employer creates a sense of trust. On the flip side, some older participants, both retired Vattenfall employees and people who never worked for Vattenfall, primarily remembered the feeling of false expectations that the construction era created. They felt that the government and Vattenfall, who at the time seemed to be the same thing, had broken their promise when most of the jobs disappeared; when Vattenfall stopped paying for local infrastructure; and when the tax policies changed to collect revenues at a national level. These examples of false expectations and feeling let down demonstrate some participants' sense of distrust towards the government and Vattenfall. When these participants talked about how they feel that Vattenfall and the government reap the benefits of the hydroelectric dams without giving enough back to Jokkmokk, they presented examples of perceived unfulfilled moral responsibilities and false expectations that create distrust.

Taking a longitudinal perspective on community acceptance revealed two insights: first, that any compensation and benefits given to a dam-affected community must be sustained for a long time- - short-term benefits intended to increase community acceptance can backfire when community members experience the withdrawal of these benefits. This is particularly important to keep in mind for projects like hydroelectric dams that employ thousands of people during the construction, but only need a fraction of the workers to maintain and operate the finished dam. Second, the difference between younger and older community members' responses suggests that it might be possible to overcome the sense of distrust that results, for example, from the initial jobs or financial support disappearing, but if at all possible, it is likely to take a very long time. A future study could explore how people from different generations perceive the impacts of old hydroelectric dams. 


\subsection{Limitations to the study}

When thinking about communities that are impacted by hydroelectric dams, selecting the most impacted community can be difficult. It is common for communities located downstream of large dams to be more negatively impacted than upstream communities and the factors that drive community acceptance in one community might not be the same as in another community. Choosing Jokkmokk as my study site meant that I was able to assess the factors influencing acceptance in a community that encompasses several dams and that is located upstream of some dams and downstream of others. As a large portion of Jokkmokk's population moved to the area because of dam construction, certain factors, such as jobs, may be particularly important to this community. Other factors, for example, the impact on subsistence fisheries, may be less important than in a community where people survived primarily as fishers before the dam-building began. Jokkmokk offered a window into community acceptance in a former dam-construction community decades after the dams were finished, but it is important to keep the limitations in mind when applying my findings to other communities.

The community members who chose to respond to the survey or volunteer to be interviewed may not accurately represent the community. While this remains a problem for studies like this one, it is reassuring to know that the survey respondents and interviewees represented both sides of the spectrum of community acceptance of the hydroelectric dams on the Lule River. Furthermore, as useful as social media can be in disseminating information and identifying participants, it limits the sample to social media users who are active in the Jokkmokk-specific Facebook groups. The demographic data confirmed that the survey reached a wide and fairly representative group of participants, but there is a possibility that my study may have failed to correctly present the opinions held by the minority of people in Sweden who do not use social media. Furthermore, the survey may have overlooked other views held by people in Jokkmokk, even though the survey was designed based on factors influencing people's perceptions of hydroelectric dams identified in other studies.

Another important limitation of my study is that due to time constraints and inaccessibility, unlike the survey respondents, the interviewees did not accurately represent the Sami people. As indigenous people bear the brunt of damming rivers (Desbiens, 2004; Össbo, 2014), future studies are needed to understand and protect the interests of these groups.

\subsection{Policy recommendations}

My study results in three policy recommendations for Swedish policymakers. First, the strong sense of distributional injustice, especially in light of the historical and legislative context, suggests that the Swedish system for distributing the revenues 
from property taxes should be reconsidered and modeled after other European countries to ensure that rural communities receive adequate compensation for the burdens and losses associated with natural resource extraction.

Second, to address the Jokkmokk residents' sense of being exploited, Sweden should consider adopting a system for sharing revenues from natural resource use with the communities most impacted by resource extraction. In the case of Jokkmokk, this could entail allowing the town of Jokkmokk to keep a percentage of the revenue from the sale of hydropower generated within the municipal boundaries. Establishing institutions for equitable sharing of revenues could help the older Jokkmokk residents overcome the sense of being left behind by the state and Vattenfall, increase the sense of outcome fairness, and consequently improve long-term community acceptance. A revenue-sharing plan would also need to assess which communities in the Lule River watershed are impacted by the hydroelectric dams; within the watershed, there could be more communities that are impacted by the dams, and a revenue-sharing system would need to carefully consider how to equitably share the benefits of hydroelectric dams with all impacted communities.

Third, the community members' perception of ecological destruction suggests that it is relevant to also consider mitigation and restoration. These efforts could include, for example, spilling a small volume of water into the dry sections of the Lule River channel. Measures that would bring the Lule River into compliance with the EU Water Framework Directive (WFD) could simultaneously remedy the Jokkmokk residents' concerns about the river ecology and aesthetics, so the Swedish government should continue to strengthen its implementation of the Directive.

\section{Conclusion}

My study set out to address the research question: "What factors most influence community acceptance of hydroelectric dams, decades after the dams were built, and what are the implications for long-term hydropower policy?"

This study shows that decades after hydroelectric dams have been built, community acceptance is influenced by distributional justice. Distributional justice here manifests in the sharing of benefits-such as revenues from electricity sales and property taxes-and burdens, for example, the negative ecological impacts of hydroelectric dams, in a way that the impacted community members perceive as equitable. Trust also plays into community acceptance and may be compromised if the level of compensation and financial support to the impacted community decreases drastically upon completion of the dam. The study suggests that with time, communities may be able to overcome distrust, as generations change, but more research is needed to understand this process. 
Because it offers a longitudinal perspective, my study begins to fill the temporal gap in the social acceptance literature and contributes to our understanding of social acceptance as a dynamic process. Understanding social acceptance necessitates iterative research processes grounded in history as well as other disciplines-it is an area for human-ecological research.

Addressing the latter part of my research question, the study identified three policy recommendations for the Swedish government to improve community acceptance of hydroelectric dams in Jokkmokk. These measures include firstly revising the policies for corporate property taxes and secondly instituting a system for sharing revenues from electricity sales with the communities where hydroelectric dams are located. Finally, there should be stronger measures for mitigating the ecological impacts of the dams on the Lule River, which in the process should bring the dams into compliance with modern environmental standards and the EU WFD. The case of hydroelectric dams in Jokkmokk highlights the urgent need for governments to balance energy production, river conservation, and economic justice.

\section{Acknowledgment}

I conducted this research as part of my senior project at the College of the Atlantic and received monetary support from the College of the Atlantic's expeditionary fund and the Rothschild Advanced Student Work Fund. I am grateful to my supervisor, Ken Cline, for his support, and to Sarah Ebel, Katrine Østerby, and Donovan Glasgow for their helpful advice. I thank the editor of this journal and two anonymous reviewers for their insightful and generous comments. Finally, I extend my gratitude to all the Jokkmokk residents who responded to the survey, participated in the interviews, and welcomed me into their community.

\section{References}

Bernard, R. H., Wutich, A., \& Ryan, G. W. (2017). Analyzing qualitative data: Systematic approaches (2nd ed.). SAGE Publications.

Bostorp, C., Hedenström, C., Nilsson, O., \& Sparrevik, E. (2014). Konsekvensanalys: Förbättringsåtgärder som kan bli aktuella för att uppnå God Ekologisk Potential (GEP) $i$ Kraftigt Modifierade Vattendrag (KMV) [Impact assessment: Improvement measures that may be needed to achieve Good Ecological Potential (GEP) in Heavily Modified Water Bodies (HMWB)]. Vattenfall.

Bronfman, N. C., Jiménez, R. B., Arevalo, P. C., \& Cifuentes, L. A. (2015). Public acceptance of electricity generation sources: The role of trust in regulatory institutions. Energy \& Environment, 26(3), 349-368. doi.org/10.1260/0958-305x.26.3.349 
Chandy, T., Keenan, R. J., Petheram, R. J., \& Shepherd, P. (2012). Impacts of hydropower development on rural livelihood sustainability in Sikkim, India: Community perceptions. Mountain Research and Development, 32(2), 117-125. doi.org/10.1659/ mrd-journal-d-11-00103.1

Deemer, B. R., Harrison, J. A., Li, S., Beaulieu, J. J., Delsontro, T., Barros, N., ... Vonk, J. A. (2016). Greenhouse gas emissions from reservoir water surfaces: A new global synthesis. BioScience, 66(11), 949-964. doi.org/10.1093/biosci/biw117

Desbiens, C. (2004). Producing north and south: A political geography of hydro development in Québec. Canadian Geographer, 48(2), 101-118. doi.org/10.1111/ j.0008-3658.2004.00050.x

Ekonomifakta. (2020, January 15). Kommunala utjämningssystemet [Municipal equalization system]. Ekonomifakta. Retrieved August 19, 2020, from www.ekonomifakta.se/Fakta/ Offentlig-ekonomi/kommunal-ekonomi/kommunala-utjamningssystemet/

Esri. (2013, July 14). Topographic [basemap]. Scale not given. World Topographic Map. Retrieved February 27, 2019, from www.arcgis.com/home/item.html?id=30e5fe3149 c34df1ba922e6f5bbf808f

Evans, B., Parks, J., \& Theobald, K. (2011). Urban wind power and the private sector: Community benefits, social acceptance and public engagement. Journal of Environmental Planning and Management, 54(2), 227-244. doi.org/10.1080/09640568.2010.505829

Finansdepartementet. (2016). Skatteförslag med anledning av energiöverenskommelsen (Pub. L. No. Fi2016/04184/S2) [Proposed tax reform based on the energy agreement]. Department of Finance (Sweden). www.regeringen.se/4ad0bb/contentassets/0dcb61261219462a98e fadd4fb9ada98/skatteforslag-med-anledning-av-energioverenskommelsen

González, A. M., Sandoval, H., Acosta, P., \& Henao, F. (2016). On the acceptance and sustainability of renewable energy projects-a systems thinking perspective. Sustainability (Switzerland), 8(11), 1171. doi.org/10.3390/su8111171

Gross, C. (2007). Community perspectives of wind energy in Australia: The application of a justice and community fairness framework to increase social acceptance. Energy Policy, 35(5), 2727-2736. doi.org/10.1016/j.enpol.2006.12.013

Gross, C. (2008). A measure of fairness: An investigative framework to explore perceptions of fairness and justice in a real-life social conflict. Human Ecology Review, 15(2), 130-140. www.jstor.org/stable/24707597

Gross, C., \& Dumaresq, D. (2014). Taking the longer view: Timescales, fairness and a forgotten story of irrigation in Australia. Journal of Hydrology, 519(Part C), 2483-2492. doi.org/10.1016/j.jhydrol.2014.08.056

Hagen, B., \& Pijawka, D. (2015). Public perceptions and support of renewable energy in North America in the context of global climate change. International Journal of Disaster Risk Science, 6(4), 385-398. doi.org/10.1007/s13753-015-0068-z 
Hannu, F. (2014, June 2). Jokkmokk rikt med norska regler [Jokkmokk wealthy by Norwegian rules]. SVT Nyheter [Swedish public service television news]. www.svt.se/ nyheter/lokalt/norrbotten/vattenkraftkommuner-ar-rika-i-norge

Hou, G., Chen, T., Ma, K., Liao, Z., Xia, H., \& Yao, T. (2019). Improving social acceptance of waste-to-energy incinerators in China: Role of place attachment, trust, and fairness. Sustainability (Switzerland), 11(6), 1727. doi.org/10.3390/su11061727

Huijts, N. M. A., Midden, C. J. H., \& Meijnders, A. L. (2007). Social acceptance of carbon dioxide storage. Energy Policy, 35(5), 2780-2789. doi.org/10.1016/j.enpol.2006.12.007

International Energy Agency. (2018). Renewables 2018: Analysis and forecasts to 2023 (Market Report Series). Organisation for Economic Co-operation and Development and International Energy Agency. doi.org/10.1787/re_mar-2018-en

IPCC. (2018). Global warming of $1.5^{\circ} \mathrm{C}$ : An IPCC Special Report on the impacts of global warming of $1.5^{\circ} \mathrm{C}$ above pre-industrial levels and related global greenhouse gas emission pathways, in the context of strengthening the global response to the threat of climate change, sustainable development, and efforts to eradicate poverty (V. Masson-Delmotte, P. Zhai, H.-O. Pörtner, D. Roberts, J. Skea, P.R. Shukla, A.Pirani, ... T. Waterfield (Eds.). Intergovernmental Panel on Climate Change. www.ipcc.ch/sr15/

Jansson, R., Nilsson, C., \& Renofalt, B. (2017). Fragmentation of riparian floras in rivers with multiple dams. Ecology, 81(4), 899-903. doi.org/10.2307/177165

Kataria, M. (2009). Willingness to pay for environmental improvements in hydropower regulated rivers. Energy Economics, 31(1), 69-76. doi.org/10.1016/j.eneco.2008.07.005

Kellner, E. (2019). Social acceptance of a multi-purpose reservoir in a recently deglaciated landscape in the Swiss Alps. Sustainability (Switzerland), 11(14), 3819. doi.org/10.3390/ su11143819

King, T. J. (2010). Damming the flow: Cultural barriers to perceived "procedural justice" in Wonthaggi, Victoria. Cultural Studies Review, 16(1), 119-130. doi.org/10.5130/csr. v16i1.1453

Länsstyrelserna \& Vattenmyndigheterna [Country Boards \& Water Boards]. (n.d.). Del 1 Åtgärdsplan för Luleälvens avrinningsområde [Part 1: Action plan for the Lule River watershed].

Lind, E. A., \& Tyler, T. R. (1988). The social psychology of procedural justice. Plenum Press. doi.org/10.1007/978-1-4899-2115-4

Lindström, A., \& Ruud, A. (2017). Whose hydropower? From conflictual management into an era of reconciling environmental concerns; A retake of hydropower governance towards win-win solutions? Sustainability (Switzerland), 9(7), 1-18. doi.org/10.3390/ su9071262 
Liu, W., Wang, C., \& Mol, A. P. J. (2013). Rural public acceptance of renewable energy deployment: The case of Shandong in China. Applied Energy, 102, 1187-1196. doi.org/ 10.1016/J.APENERGY.2012.06.057

Malesios, C., \& Arabatzis, G. (2010). Small hydropower stations in Greece: The local people's attitudes in a mountainous prefecture. Renewable and Sustainable Energy Reviews, 14(9), 2492-2510. doi.org/10.1016/j.rser.2010.07.063

Mueller, M., Pander, J., \& Geist, J. (2011). The effects of weirs on structural stream habitat and biological communities. Journal of Applied Ecology, 48(6), 1450-1461. doi.org/ $10.1111 / j .1365-2664.2011 .02035 . x$

Össbo, Å. (2014). Nya vatten, dunkla speglingar: Industriell kolonialism genom svensk vattenkraftutbyggnad i renskötselområdet 1910-1968 [New waters, reflections of obscurity: Industrial colonialism through the Swedish hydropower development in reindeerherding regions 1910-1968] [Unpublished doctoral dissertation]. Umeå University.

Pidgeon, N., \& Demski, C. C. (2012). From nuclear to renewable: Energy system transformation and public attitudes. Bulletin of the Atomic Scientists, 68(4), 41-51. doi.org/10.1177/0096340212451592

Renöfält, B. M., Jansson, R., \& Nilsson, C. (2010). Effects of hydropower generation and opportunities for environmental flow management in Swedish riverine ecosystems. Freshwater Biology, 55(1), 49-67. doi.org/10.1111/j.1365-2427.2009.02241.x

RStudio Team. (2011). RStudio: Integrated development for $R$ (Version 1.3.1093) [Computer software]. RStudio Inc. rstudio.com

Siergieiev, D., Widerlund, A., Lundberg, A., Almqvist, L., Collomp, M., Ingri, J., \& Öhlander, B. (2014). Impact of hydropower regulation on river water composition in Northern Sweden. Aquatic Geochemistry, 20(1), 59-80. doi.org/10.1007/s10498-0139215-6

Söderasp, J. (2018). Law in integrated and adaptive governance of freshwaters: A study of the Swedish implementation of the EU Water Framework Directive [Unpublished doctoral dissertation]. Luleå University of Technology.

Soland, M., Steimer, N., \& Walter, G. (2013). Local acceptance of existing biogas plants in Switzerland. Energy Policy, 61, 802-810. doi.org/10.1016/j.enpol.2013.06.111

Statistiska Centralbyrån [Statistics Sweden]. (2017). 80 procent av elen kommer från vattenkraft och kärnkraft [80 percent of electricity comes from hydropower and nuclear power]. Retrieved January 17, 2018, from web.archive.org/web/20171222100559/ www.scb.se/hitta-statistik/sverige-i-siffror/miljo/energi/

Statistiska Centralbyrån [Statistics Sweden]. (n.d.). Kommuner i siffror [Municipalities in figures]. Retrieved March 4, 2019, from www.statistikdatabasen.scb.se/pxweb/en/ssd/ 
Strand, H.-U. (1984). Vattenkraftsutbyggnaden i Lule älv: Betydelse för befolkning, försörjning, och industrietableringar [Hydropower developments in the Lule River: Implications for population, supply and industrial establishments]. Daedalus, 1984, 239-260.

Tabi, A., \& Wüstenhagen, R. (2017). Keep it local and fish-friendly: Social acceptance of hydropower projects in Switzerland. Renewable and Sustainable Energy Reviews, 68(Part 1), 763-773. doi.org/10.1016/j.rser.2016.10.006

Tefera, B., \& Stroosnijder, L. (2007). Integrated watershed management: A planning methodology for construction of new dams in Ethiopia. Lakes and Reservoirs: Research and Management, 12(4), 247-259. doi.org/10.1111/j.1440-1770.2007.00340.x

Vattenfall. (2019). About our power plants and the production. Vattenfall. Retrieved September 18, 2019, from powerplants.vattenfall.com/\#/types=Hydro/view=map/sort= name

Vattenmyndigheterna, Länsstyrelserna, \& Havs och Vattenmyndigheten [Water Boards, County Boards, \& Swedish Agency for Marine and Water Management]. (2020). Luleälven [Lule River] - WA80573188 / SE730636-177276. VISS (Vatteninformationsystem Sverige [Water information system Sweden)]. viss.lansstyrelsen.se/Waters.aspx?waterMSCD= WA80573188

Wolsink, M. (2018). Social acceptance revisited: Gaps, questionable trends, and an auspicious perspective. Energy Research and Social Science, 46(August), 287-295. doi.org/ $10.1016 /$ j.erss.2018.07.034

World Commission on Dams. (2000). Dams and development: A new framework for decisionmaking. Earthscan.

World Energy Council. (2018). World energy issues monitor 2018: Perspectives on the grand energy transition. www.worldenergy.org/publications/entry/world-energy-issuesmonitor-2018-perspectives-on-the-grand-energy-transition

Wüstenhagen, R., Wolsink, M., \& Bürer, M. J. (2007). Social acceptance of renewable energy innovation: An introduction to the concept. Energy Policy, 35(5), 2683-2691. doi.org/10.1016/j.enpol.2006.12.001 
This text is taken from Human Ecology Review, Volume 27, Number 1, 2021, published by ANU Press, The Australian National University, Canberra, Australia.

doi.org/10.22459/HER.27.01.2021.06 